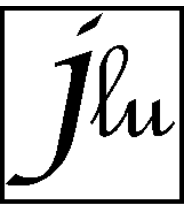

https://jurnal.univpgripalembang.ac.id/index.php/luminous
Jurnal Luminous:

E-ISSN 2715-6990

P-ISSN 2715-9582

Riset Ilmiah Pendidikan Fisika

Vol. 1 No. 2 (2020) hal 1-7
Juli 2020

\title{
IMPLEMENTASI MODEL PEMBELAJARAN GUIDED INQUIRI UNTUK MENINGKATKAN KETERAMPILAN PROSES SAINS DAN HASIL PENGETAHUAN KOGNITIF SISWA
}

\author{
Nuayi, A. $W^{1 \star}$, Very $^{2}$ \\ ${ }^{1} J u r u s a n$ fisika, Fakultas Matematika dan IPA, Universistas Negeri Gorontalo \\ Bone Bolango, Gorontalo \\ Wahidin.awn2023@ung.ac.id \\ ${ }^{2}$ Jurusan fisika, Fakultas Matematika dan IPA, Universistas Negeri Gorontalo \\ Kota Gorontalo,Gorontalo \\ Very.s1fisika12@gmail.com
}

Received: 20 April 2020. Accepted: 25 Juni 2020. Published: Juli 2020

\begin{abstract}
Abstrak
Tujuan dari penelitian ini adalah untuk meningkatkan keterampilan proses sains dan hasil belajar kognitif siswa dalam pembelajaran fisika melalui penggunaan model pembelajaran inkuiri terbimbing. Penelitian ini merupakan Penelitian Tindakan Kelas (PTK) yang dilakukan dalam 2 siklus yang terdiri dari 4 fase yaitu perencanaan, tindakan, observasi, dan refleksi pada setiap siklusnya. Subjek penelitian ini adalah siswa kelas XI IPA 3 SMA Negeri 1 Kabila tahun ajaran 2018/2019 yang berjumlah 36 orang, terdiri dari 12 siswa laki-laki dan 24 siswa perempuan. Data dalam penelitian diperoleh melalui observasi, tes, dan dokumentasi. Data yang diperoleh dianalisis menggunakan teknik deskriptif kualitatif. Hasil data yang diperoleh menunjukkan bahwa persentasi skor rerata semua aspek keterampilan proses sains dan hasil belajar kognitif siswa mengalami peningkatan dari 36,43 dan 33, 42 di siklus pertama menjadi 90,86 dan 92,06 pada siklus kedua. Sedangkan untuk pengamatan aktivitas guru, pada siklus pertama telah terlaksana dengan presentase $87,5 \%$ atau dalam kategori baik, meningkat menjadi $95,83 \%$ atau dengan kategori sangat baik pada siklus kedua. Hasil ini menunjukkan bahwa penggunaan model inkuiri terbimbing dapat meningkatkan keterampilan proses sains siswa, hasil belajar kognitif siswa, serta aktivitas guru.
\end{abstract}

Katakunci: hasil belajar, inkuiri terbimbing, keterampilan proses sains, pembelajaran fisika

\section{PENDAHULUAN}

Pendidikan bukanlah sesuatu yang statis melainkan sesuatu yang dinamis sehingga menuntut adanya usaha untuk perbaikan yang terus menerus. Siswa harus memiliki kemampuan untuk berbuat sesuatu dengan menggunakan proses dan prinsip keilmuan yang telah dikuasai, dan learning to know (pembelajaran untuk tahu) dan learning to do (pembelajaran untuk berbuat) harus dicapai dalam kegiatan belajar mengajar [1]

Fisika merupakan salah satu bagian dari IImu Pengetahuan Alam yang mempelajari tentang fenomena alam atau tingkah laku alam dan berbagai bentuk gejalanya [2]. Berdasarkan hal tersebut, maka dalam belajar fisika tidak cukup dengan belajar dari buku atau mendengar penjelasan dari orang lain, melainkan haruslah 
dengan proses inkuiri ilmiah. Pembelajaran fisika dipandang sebagai suatu proses berpikir untuk mengembangkan kemampuan dalam memahami konsep, prinsip, maupun hukum-hukum fisika, sehingga dalam proses kegiatan pembelajaran harus mempertimbangkan strategi dan metode pembelajaran yang efektif dan efisien. Oleh karena itu dalam pembelajaran fisika, siswa perlu diarahkan untuk mencari tahu konsep-konsep fisika terbentuk, sehingga dengan pembelajaran tersebut diharapkan keterampilan proses sains siswa dapat terbentuk

Keterampilan proses sains merupakan seluruh keterampilan ilmiah yang dapat digunakan untuk menemukan dan mengembangkan suatu konsep, prinsip, atupun teori serta digunakan untuk menyangkal suatu penemuan sebelumnya. Keterampilan proses sains dikembangkan dengan tujuan agar siswa terbiasa untuk menemukan suatu pengetahuan/konsep sendiri seiring dengan perkembangan IPTEK yang semakin meningkat, untuk melatih siswa berpikir kritis dan juga untuk melatih siswa dalam mengembangkan pikiran (kognitif) melalui kegiatan ilmiah [3].

Namun kenyataannya dilapangan masih jarang guru-guru fisika yang memperhatikan keterampilan proses sains. Guru lebih sering menerapkan model pembelajaran yang berpusat pada guru, dimana siswa hanya menerima informasi/pengetahuan dari guru tanpa mengetahui bagaimana informasi dapat terbentuk, kemudian juga siswa hanya dipelajari rumusrumus jadi, tanpa mengetahui makna atau arti fisis dari rumus tersebut. Hal inilah yang menyebabkan siswa beranggapan bahwa fisika merupakan pelajaran yang sangat sulit dan hanya berisi rumus-rumus matematis yang membingungkan.

Pernyataan di atas diperkuat melalui hasil wawancara dengan guru bidang studi fisika serta observasi dalam pembelajaran fisika di SMA Negeri 1 Kabila yang menyatakan bahwa model pembelajaran yang sering digunakan adalah model pembelajaran direct intruction, dengan metode pembelajarannya yaitu metode ceramah, diskusi, dan tanya jawab. Selain ketiga metode tersebut guru juga menggunakan metode praktikum dan demonstrasi namun itu jarang dilakukan. Siswa jarang dilibatkan dalam kegiatan merancang percobaan meliputi penentuan alat bahan, variabel, serta langkah kerja percobaan. Kegiatan praktikum yang dilaksanakan hanya berpedoman pada petunjuk dari guru. Minimnya tingkat keterlibatan siswa dalam pembelajaran fisika mengakibatkan keterampilan proses sains siswa kurang terlatih. Dalam pembelajaran masih didominasi oleh guru dimana guru menjelaskan materi/konsep fisika melalui metode ceramah kemudian siswa diberi soal-soal latihan yang sesuai dengan materi yang diajarkan dengan tujuan agar siswa menguasai materi tersebut. Pembelajaran belum diarahkan untuk menemukan konsep-konsep fisika sesuai dengan hakikat fisika yaitu proses-produk. Akibat dari pembelajaran tersebut, siswa masih kesulitan dalam menyelesaikan soal-soal fisika yang berdasarkan permasalahan dalam kehidupan sehari-hari yang menuntut siswa untuk menalar atau menganalisis soal tersebut sebelum ia menjawab.

Berdasarkan uraian di atas, terlihat bahwa pembelajaran yang berlangsung memperlihatkan siswa kurang terampil dan aktif mengikuti proses pembelajaran, siswa cenderung lebih banyak diam dan sekedar memperhatikan materi yang disampaikan. Berdasarkan analisis hasil observasi, disimpulkan bahwa akar masalah keterampilan proses sains yang rendah disebabkan karena model pembelajaran yang diterapkan belum optimal melatihkan keterampilan proses sains, sehingga diperlukan model pembelajaran yang mampu memberdayakan keterampilan proses sains siswa, memberikan kesempatan kepada siswa untuk melakukan penyelidikan/eksperimen dalam membentuk pengetahuan/konsep-konsep fisika. Salah satu model pembelajaran yang menekankan pada keterampilan proses sains, kemampuan berpikir, dan menekankan pada penyelidikan secara ilmiah adalah model pembelajaran inkuiri terbimbing (Guided Inquiry).

Penerapan model pembelajaran yang sesuai akan menghasilkan proses pembelajaran yang efektif. Model pembelajaran adalah kerangka 
konseptual yang digunakan sebagai pedoman dalam melakukan pembelajaran yang disusun secara sistematis untuk mencapai tujuan belajar. Salah satu langkah yang bisa dilakukan oleh guru sebagai pembimbing siswa dalam kegiatan pembelajaran di sekolah adalah memilih model pembelajaran yang tepat $[4,5,6]$. Pembelajaran dengan menggunakan model pembelajaran inkuiri terbimbing dipandang sesuai untuk diterapkan dalam pembelajaran fisika karena siswa dapat terlibat secara aktif dalam proses pembelajaran untuk mencari dan menyelidiki secara sistematis dengan bimbingan dan petunjuk dari guru. Senada dengan hal tersebut, model pembelajaran inkuiri adalah salah satu tipe model pembelajaran yang menekankan pada aktivitas, keterampilan, serta pengetahuan melalui pencarian aktif berdasarkan pada rasa keingintahuan serta merupakan salah satu model pembelajaran yang membantu siswa untuk memahami konsep dan mengembangkan keterampilan proses sains melalui tahapan ilmiah.[7,8].

Tahap pembelajaran inkuiri terdiri dari observasi, mengajukan pertanyaan, merumuskan hipotesis, merancang percobaan, melaksanakan percobaan, mengumpulkan data, analisis data, argumentasi [9,10]. Dengan memperhatikan bahwa tahapan pembelajaran yang dimiliki model pembelajaran inkuiri identik dengan aspek keterampilan proses sains meliputi observasi, klasifikasi, bertanya, berhipotesis, merencanankan percobaan, menggunakan alat bahan, menerapkan konsep, mengkomunikasikan, serta melakukan percobaan, maka model pembelajaran inkuiri terbimbing dapat digunakan untuk meningkatkan keterampilan proses sains melalui penerapan tiap langkah pembelajaran yang dimiliki $[10,11,12,13]$.

Sehingga dengan memperhatikan paparan uraian yang dikemukakan di atas, maka tujuan penelitian ini adalah untuk meningkatkan keterampilan proses sains dan hasil belajar kognitif siswa dalam pembelajaran fisika melalui penggunaan model pembelajaran inkuiri terbimbing.

\section{METODE}

Penelitian ini merupakan Penelitian Tindakan Kelas (PTK) atau Classroom Action Research (CAR) yang bertujuan untuk meningkatkan keterampilan proses sains dalam pembelajaran fisika. Prosedur dan langkahlangkah dalam penelitian tindakan kelas ini mengikuti model yang dikembangkan oleh Kemmis dan Mc.Taggart [14] berupa model spiral yaitu dalam satu siklus terdiri dari tahap perencanaan, tindakan, observasi, dan refleksi yang dilakukan dalam 2 siklus yang terdiri dari 4 fase yaitu perencanaan, tindakan, observasi dan refleksi pada setiap siklusnya. Pada setiap siklus terdiri dari 4 pertemuan yaitu 3 kali tatap muka dan 1 kali evaluasi sehingga jumlah pertemuan sebanyak 10 kali.

Tahap perencanaan pembelajaran meliputi penyusunan instrumen pembelajaran dan instrumen penelitian. Instrumen pembelajaran terdiri dari silabus, RPP, LKS, dan materi ajar, sedangkan instrumen penelitian terdiri dari lembar observasi, soal keterampilan proses sains, lembar observasi keterampilan proses sains dan keterlaksanaan sintaks, pedoman wawancara, serta peralatan dokumentasi.

Subyek penelitian ini adalah siswa kelas XI IPA SMA Negeri 1 Kabila tahun pelajaran 2018/2019 yang berjumlah 36 orang, terdiri dari 12 siswa laki-laki dan 24 siswa perempuan

Penelitian dilakukan berkolaborasi dengan guru fisika untuk menyelesaikan permasalahan keterampilan proses sains siswa yang dianalisis melalui hasil observasi dan tes hasil belajar. Solusi dari permasalahan di kelas XI IPA 3 berupa penerapan model pembelajaran inkuiri terbimbing dalam pembelajaran fisika pada materi Elastistas bahan dan Fluida. Penerapan model pembelajaran inkuiri dilakukan dalam 2 siklus pembelajaran, dengan langkah pembelajaran yang sama. Perbedaan yang terdapat antar siklus adalah bagian refleksi, sebab refleksi didasarkan pada fakta yang diperoleh dari pelaksanaan di lapangan. Kegiatan refleksi tiap siklus dilakukan 
untuk mengupayakan perbaikan pembelajaran siklus berikutnya

Data dalam penelitian diperoleh melalui observasi, tes, dan dokumentasi. Data yang diperoleh dianalisis menggunakan teknik deskriptif kualitatif. Indikator keterampilan proses sains yang diteliti dalam penelitian ini adalah (1) merumuskan masalah, (2) merumuskan hipotesis, (3) mengidentifikasi variabel, (4) mendefinisikan variabel secara operasional, (5) merencanakan dan melakukan pemecahan masalah, (6) melaksanakan percobaan, (7) melakukan pengamatan dan pengumpulan data, (8) menginterprestasikan/ menafsirkan data, (9) memprediksi, dan (10) mengkomunikasikan. Instrumen pengumpulan data yang digunakan dalam penelitian ini yaitu lembar penilaian observasi dan dokumentasi hasil Lembar Kerja Siswa.

Data hasil belajar siswa diperoleh melalui hasil hasil post-test. Indikator belajar yang akan diukur dalam penelitian ini juga mengacu pada indikator keterampilan proses sains dengan instrumen pengumpulan data yang digunakan dalam penelitian ini berupa soal tes. Target capaian yang ditetapkan diakhir tindakan adalah sebesar $75 \%$ untuk ketuntasan individual, sedangkan untuk ketuntasan klasikal adalah $85 \%$ siswa memiliki skor $\geq 75 \%$.

\section{HASIL DAN PEMBAHASAN}

\section{Keterampilan Proses Sains Siswa, Hasil Belajar Siswa dan Aktivitas Guru}

Skor hasil capaian keterampilan proses sains (KPS) siswa yang diperoleh pada kegiatan siklus 1 dan siklus 2 sebagaimana disajikan pada Tabel 1.

Berdasarkan analisis observasi keterampilan proses sains siswa pada siklus I seperti yang ditunjukan pada Tabel 1 , didapatkan bahwa persentasi skor rerata aspek keterampilan proses sains dan hasil belajar kognitif siswa mengalami peningkatan yang sebelumnya 36,43 menjadi 90,86 pada siklus II. Skor capaian pada akhir siklus untuk setiap aspek menunjukkan peningkatkatan bila dibandingkan siklus I dengan rerata skot berkisar antara $85,25 \%$ sampai $94,75 \%$, dengan rerata skor total keseluruhan aspek mencapai 90,86\%. Skor tersebut menunjukkan adanya peningkatan keterampilan proses sains di akhir siklus dibandingkan dengan siklus I. Hasil pengukuran keterampilan proses sains siswa di akhir tindakan menunjukkan bahwa keseluruhanr aspek sudah mencapai target akhir sebesar $\geq 75 \%$.

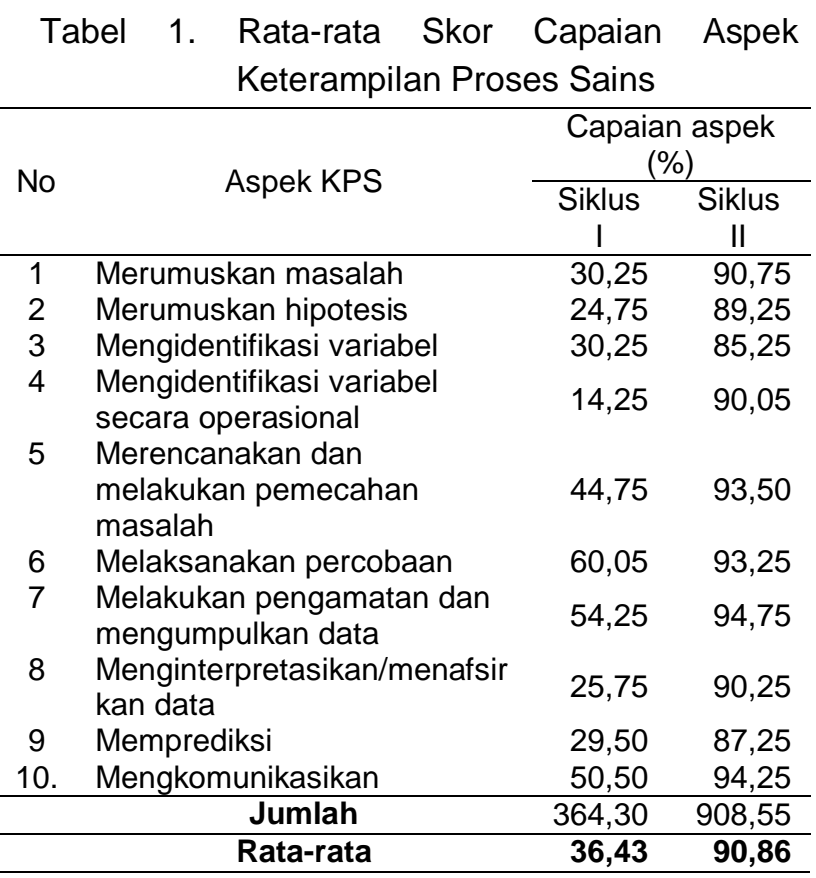

Skor capaian tiap aspek keterampilan proses sains saling berkaitan satu sama lain. Keterampilan merumuskan masalah yang baik akan memberikan dampak bagi peningkatan aspek merumuskan hipotesis dan memprediksi. Peningkatan aspek merumuskan hipotesis serta memprediksi mempengaruhi peningkatan aspek menetukan variabel dan mengidentifikasi definisi operasiobal variabel dan merancang percobaan. Keterampilan merumuskan hipotesis dan merancang percobaan yang meningkat selanjutnya berdampak pada keterampilan siswa dalam melakukan percobaan. 
Hasil dari pelaksanaan percobaan yang meningkat mengakibatkan peningkatan keterampilan menginterpretasikan/menafsirkan data. Data hasil interpretasi yang baik berdampak positif terhadap peningkatan keterampilan mengkomunikasikan hasil dan penarikan kesimpulan akhir pembelajaran.

Ditinjau dari hasil belajar siswa, dapat dilihat pula bahwa pada siklus akhir terdapat peningkatan persentase rerata skor hasil belajar siswa secara klasikal dari siklus I sebesar 33,42 menjadi 92.06 sebagaimana yang disajikan pada Gambar 1

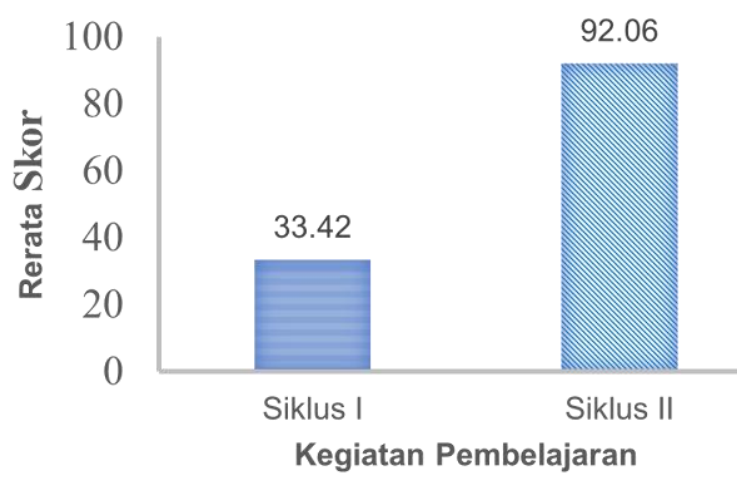

Gambar 1. Hasil Belajar Siswa

Pada siklus I, baik secara klasikal maupun individual, siswa yang tidak tuntas mencapai $100 \%$. Hal ini disebabkan oleh karena siswa belum mempunyai pengalaman dalam menyelesaikan soal-soal yang berbasis keterampilan proses. Pada siklus akhir, ketuntasan siswa secara individual mencapai $100 \%$ dengan skor rerata hasil belajar klasikal sebesar 92,06. Artinya hasil yang diperoleh pada siklus akhir telah mencapai target ketuntasan yaitu jumlah siswa dengan skor minimal 75 lebih besar dari $85 \%$.

Demikian juga hasil pengamatan aktivitas guru, dari 24 ativitas guru seperti yang disajikan pada gambar 2, terlihat bahwa dari 24 langkah kegiatan dalam pembelajaran pada siklus I, jumlah aktivitas yang terlaksana sebesar 87,5\%, kemudian pada siklus akhir aktivitas yang terlaksana meningkat menjadi $95,83 \%$.
Hasil penelitian menunjukkan bahwa penerapan model pembelajaran inkuiri terbimbing dapat meningkatakan keterampilan proses sains siswa kelas XI IPA 3 SMA Negeri 1 Kabila tahun pelajaran 2018/2019. Peningkatan yang terjadi tiap siklus terutama dipengaruhi oleh penerapan model pembelajaran inkuiri terbimbing. Inkuiri terbimbing merupakan bagian yang penting dari pengembangan keterampilan proses sains yang digunakan oleh para peneliti dalam melaksanakan penyeledikan, dimana model pembelajaran inkuiri terbimbing juga dapat mengakomodasi siswa dalam melatihkan keterampilan proses sains melalui tahap pembelajaran yang dimiliki $[11,16]$.

Tahap pembelajaran model pembelajaran inkuiri yang dapat mengakomodasi keterampilan proses sains terdiri dari kegiatan observasi, mengajukan pertanyaan, merumuskan hipotesis, merencanakan dan melaksanakan percobaan, mengumpulkan data, dan mengkomunikasikan hasil.

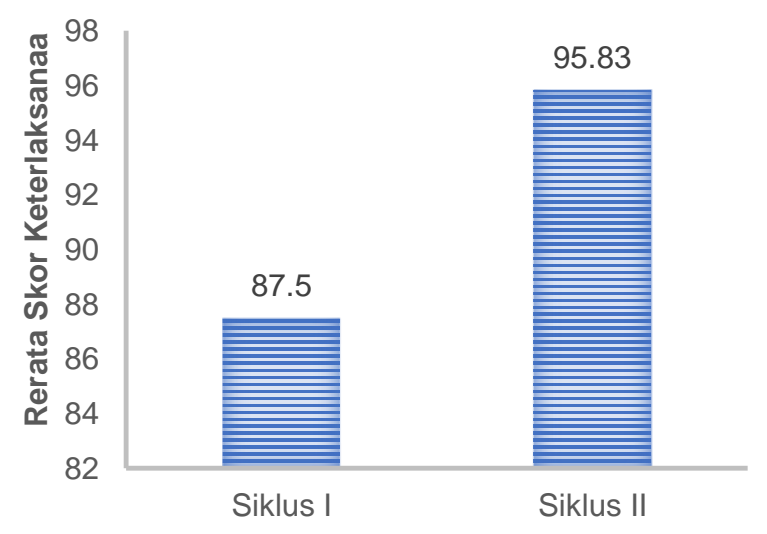

Kegiatan Pembelajaran

Gambar 2. Aktivitas Guru

Dalam pembelajaran dengan model inkuiri terbimbing siswa diharuskan melakukan penyelidikan secara ilmiah yaitu melalui perumusan masalah, membuat hipotesis, mengumpulkan data melalui percobaan, menganalisis data tersebut kemudian menyimpulkan. Semua kegiatan tersebut mengharuskan siswa untuk berperan aktif dalam proses pembelajaran (penerimaan pengetahuan) melalui keterampilan proses ilmiah. Hal tersebut 
sesuai dengan teori kontruktivisme yang menyarankan bahwa pembelajaran yang baik adalah pembelajaran yang melibatkan keterlibatan siswa dalam proses penerimaan informasi [18].

Faktor lain yang mendukung peningkatan tiap siklus adalah kualitas pembelajaran yang semakin baik. Proses pembelajaran pada tahap siklus II lebih baik dibandingkan siklus I. Peningkatan kualitas dan keterlaksanaan proses pembelajaran mengakibatkan ketercapaian skor tiap aspek menjadi lebih tinggi. Perkembangan siswa dalam penelitian tindakan kelas dipengaruhi oleh perbaikan kualitas pembelajaran yang diterapkan oleh guru, guru melakukan perbaikan pembelajaran tiap siklus melalui tahap refleksi dan perencanaan kembali sebagai upaya perbaikan siklus berikutnya [19]. Jadi, semakin baik kualitas pembelajaran yang dikelola oleh guru di kelas, semakin besar peningkatan kualitas siswa.

Peningkatan tiap siklus juga dipengaruhi oleh faktor kebiasaan. Pembelajaran yang berlangsung tiap siklus memiliki kesamaan tahaptahap yang dilaksanakan, mulai dari melakukan pengamatan hingga pada menyimpulkan hasil. Kegiatan yang selalu dilakukan berulang-ulang menyebabkan siswa maupun guru terbiasa dengan kegiatan tersebut. Kegiatan yang dilakukan dapat melatihkan keterampilan proses sains secara efektif sehingga dapat meningkatkan keterampilan proses sains siswa hingga mencapai target di akhir siklus II. Selain faktor kebiasaan, peran serta teman se-kelompok juga berpengaruh. Dalam kegiatan pembelajaran, siswa duduk berkelompok, namun ketika menyusun rumusan masalah, hipotesis, mengidentifikasi variabel serta merancang percobaan siswa dituntut untuk melakukan sendiri terlebih dahulu, kemudian setelah itu mereka berdiskusi dalam kelompok untuk memutuskan memilih mana dari hasil masing-masing anggota kelompok menjadi hasil akhir dari kelompok mereka. Dengan demikian dapat diasumsikan bahwa siswa dengan kemampuan kurang belajar lebih banyak bekerja berdampingan dengan mereka yang memiliki kemampuan lebih dan kelompok yang berkemampuan lebih ini mendapatkan manfaat dari proses berperan sebagai tutor bagi temantemannya yang kurang mampu [20].

\section{Respon Guru dan Siswa Tentang Penerapan Model Guided Inquiry}

Dari hasil wawancara dengan guru bidang studi fisika yang dilakukan setelah pembelajaran menyatakan bahwa model inkuiri terbimbing perlu diterapkan dalam pembelajaran fisika, karena siswa lebih aktif dalam pembelajaran, mampu meningkatkan, keterampilan proses siswa dan membuat siswa menjadi lebih mandiri dalam menemukan konsep-konsep fisika. Sementara menurut siswa menyatakan bahwa pembelajaran dengan menggunakan model inkuiri terbimbing membuat siswa mudah memahami konsep/materi fisika yang diajarkan, hal ini dikarenakan karena dalam pembelajaran siswa menerima pengetahuan/konsep fisika langsung dari pengalamannya sendiri. Kemudian dengan penguatan yang diberikan guru setelah percobaan, membuat informasi yang didapat semakin berkesan/bermakna dihati siswa, sehingga setelah pembelajaran informasi tersebut tidak langsung hilang dengan sendirinya

Sedangkan tanggapan siswa setelah diberi perlakuan dinilai dengan angket yang diberikan pada siswa. Lembar angket digunakan untuk mengetahui tanggapan siswa setelah proses pembelajaran selesai. Lembar angket diisi oleh seluruh siswa diakhir pertemuan setelah program selesai diberikan. Angket yang diisi oleh siswa dibagi menjadi beberapa aspek dan indikator.

Aspek yang pertama yaitu sikap siswa terhadap pelajaran fisika, aspek ini dibagi menjadi dua indikator. Indikator yang pertama yaitu minat siswa untuk mempelajari fisika setelah kegitan berlangsung, hasil yang didapatkan yaitu sangat positif, dengan tanggapan siswa sebesar $86,5 \%$ menyatakan bahwa minat mereka terhadap fisika meningkat disebabkan oleh pemberian motivasi dan apersepsi setiap sebelum memulai pembelajaran. Siswa setuju jika fisika menjadi salah satu jalan untuk mencapai tujuan siswa, hal 
ini disebabkan karena siswa mengalami sendiri pentingnya mempelajari fisika dalam rangka mewujudkan impian masing-masing siswa. Indikator kedua yaitu proses pembelajaran yang dilakukan, siswa menanggapi positif dengan pembelajaran yang dilakukan karena menyenangkan. Hal ini disebakan karena siswa diajarkan bagaiman cara seorang ilmuan bekerja. Tanggapan ini sesuai dengan prinsip pembelajaran guided inquiry yaitu pembelajaran yang menuntut siswa untuk dapat berfikir dan bertindak sebagai seorang peneliti/imuan $[7,9]$. Selain itu, siswa sangat setuju jika ada demonsrasi alat peraga dalam pembelajaran yang dilakukan, semua siswa menyukai demonstrasi alat peraga di dalam kelas. Pada pertanyaan ini tanggapan yang diberikan siswa sebesar $100 \%$ yang masuk pada kategori sangat positif.

Aspek yang kedua yaitu sikap siswa terhadap proses pembelajaran fisika yang dibelajarkan dengan menggunakan model Guided Inquiry. Aspek ini dibagi menjadi dua indikator. Indikator yang pertama yaitu minat terhadap pembelajaran fisika dengan model tersebut. Pembelajaran dengan model yang diterapkan ternyata mampu membuat siswa tertarik dengan materi yang dipelajari sehingga mendapat tanggapan positif, sehingga membuat siswa lebih termotivasi belajar fisika, siswa sangat setuju jika terdapat aplikasi materi dalam kehidupan seharihari, dengan tanggapan $88 \%$ yang masuk dalam kategori Tinggi. Dalam belajar di kelas siswa mempunyai gaya belajar yang berbeda-beda antara satu siswa dengan siswa lainnya. Siswa memiliki gaya belajar alami dan nyaman untuk siswa belajar di dalam kelas, sehingga setiap siswa mempunyai gaya belajarnya masingmasing.

Indikator selanjutnya yaitu menunjukkan kegunaan LKPD berbasis inkuiry yang diberikan oleh guru, sebagian besar siswa merasa tidak keberatan dan tau bahwa besar manfaat dari pembuatan LKPD ini. Ttanggapan siswa sangat positif jika pembuatan LKPD berbasis inkuiri mampu membuat mereka lebih mudah mengerti konsep yang dibelajarkan dengan tanggapan untuk pertanyaan ini sebesar $88,25 \%$ dengan kategori tinggi. Hal ini dapat disebabkan LKPD berbasis inkuiri tidak secara langsung meningkatkan kemampuan proses sains siswa..

Dengan demikian, penggunaan model inkuiri terbimbing dapat meningkatkan keterampilan proses sains siswa, hasil belajar kognitif siswa, serta aktivitas guru

\section{KESIMPULAN DAN SARAN}

Model inkuiri terbimbing dapat digunakan dalam meningkatkan keterampilan proses sains siswa, hasil belajar kognitif siswa, serta aktivitas guru pada pelajaran fisika topik fluida pada kelas XI IPA 3 SMA Negeri 1 Kabila. Hal ini ditunjukkan dengan hasil penelitian yang diperoleh memperlihatkan terjadinya peningkatan persentasi skor rerata semua aspek keterampilan proses sains dan hasil belajar kognitif siswa dari 36,43 dan 33, 42 di siklus pertama menjadi 90,86 dan 92,06 pada siklus kedua. Sedangkan untuk pengamatan aktivitas guru, pada siklus pertama telah terlaksana dengan presentase $87,5 \%$ atau dalam kategori baik, meningkat menjadi 95,83\% atau dengan kategori sangat baik pada siklus kedua.

Saran disusun berdasarkan temuan penelitian yang telah dibahas. Saran dapat mengacu pada tindakan praktis, pengembangan teori baru, dan/atau penelitian lanjutan.

\section{UCAPAN TERIMA KASIH}

Ucapan terimakasih ditujukan kepada Direktorat Pembelajaran dan Kemahasiswaan Ditjen KEMRISTEK DIKTI yang telah mendanai penelitian ini melalui program Penugasan Dosen di Sedkolah (PDS) Tahun Anggaran 2018 sesuai kontrak pelaksanaan Hibah PDS Nomor: 51/B2.PPK/SPPK/PDS/2018. 


\section{DAFTAR PUSTAKA}

[1] Ambarsari, Santosa, dan Maridi. (2013). Penerapan Pembelajaran Inkuiri Terbimbing Terhadap Keterampilan Proses Sains Dasar Pada Pelajaran Biologi Siswa Kelas VIII SMP Negeri 7 Surakarta. J. Pendidikan Biologi, Vol. 5 (01): 81-95.

[2] Pelita, P. D. (2011). Efektivitas Penggunaan Video Based Laboratory Pada Pembelajaran Konseptual Interaktif Dalam Meningkatkan Pemahaman Grafik dan Keterampilan Berpikir Logis. Jurnal penelitian-pendidikan, Vol. 2 (1): 364-374.

[3] Mutisya, S.M., Rotich, S. \& Rotich, P.K. (2013). Conceptual Understanding Of Science Process Skills and Gender Stereotyping: A Critical Component For Inquiry Teaching Of Science In Kenya's Primary Schools. Journal of Social Science \& Humanities, 2(3): 359369.

[4] Aristianti E, Susanto H \& Marwoto P. (2018). Implementasi Model Pembelajaran Inquiri Terbimbing Terhadap Kemampuan Pemecahan Masalah dan Komunikasi Siswa SMA. Unnes Phyasics Journal Vol. 7 (1): (6872)

[5] Setiasih, S. P. (2016). Penggunaan Model Inkuiri Untuk Meningkatkan Hasil Belajar Siswa Pada Materi Sifat-sifat Magnet di Kelas V SDN Sukajaya Kecamatan Jatinunggal Kabupaten Sumedang. Pena IImiah , 1 (1), 421-430.

[6] Sukmawati, A. \& M. Sari. (20150. Implementasi Model Pembelajaran Berbasis Masalah pada Pemecahan Masalah Matematika di Kelas VIII SMP. Jurnal Pendidikan Matematika, 3(1): 75-83.

[7] Bell, T., Urhahne, D., Schanza, S., \& Ploetzner, R. (2013). Collaborative Inquiry Learning: Models, Tools, and Challenges. International Journal of Science Education. 32(3): 349-377.

[8] Jack, G.U. (2013). The Influence of Identified Student and School Variables on Student Science Process Skill Acquisition. Journal of Education and Practice. 4(5): 16-22.

[9] Joyce, B., Weil, M., \& Calhoun, E., (2000.) Models of Teaching - Sixth Edition. Allyn and Bacon

[10] Azizah N, Indrawati \& Harijanto A. 2014. Penerapan Model Inkuiri Terbimbing untuk Meningkatkan Keterampilan Proses Sains dan Hasil Belajar
Fisika Kelas X.C di MAN 2 Jember Tahun Ajaran 2013/2014. Jurnal Pendidikan Fisika Vol. 3 No. 3: 235-239.

[11] Nurhudayah M, Lesmono D.A \& Subiki. 2016. Penerapan Model Inkuiri Terbimbing (Guided Inquiri) dalam Pembelajaran Fisika SMA di Jember. Jurnal pembelajaran fisika Vol.5 (1): 82-88

[12] Rustaman, N.Y. (2005). Perkembangan Penelitian Pembelajaran Berbasis Inkuiri dalam Pendidikan Sains. Makalah seminar Nasional II. Bandung.

[13] Iswatun, I., Mosaik, M. \& Subali B. 2017. Penerapan Model Pembelajaran Inkuiri Terbimbing untuk Meningkatkan KPS dan Hasil Belajar Siswa SMP Kelas VIII. Jurnal Ivovasi Pendidikan IPA, Vol 3 (2):151-160

[14] Kemmis, S \& M Spektor-Levy, O., B.S. Eylon, \& Z. Scherz. (2009). Teaching scientific communication skills in science studies: does it make a difference?. International Journal of Science and Mathematics Education, Vol.7(5) : 875-903. ctaggart, R. (2005). Participatory Action Research: Handbook of Qualitative Research.

[15] Spektor-Levy, O., Eylon, B.S., \& Scherz, Z., (2009). Teaching scientific communication skills in science studies: does it make a difference?. International Journal of Science and Mathematics Education, 7(5) : 875-903.

[16] Juhji. 2016. Peningkatan Keterampilan Proses Sains Siswa Melalui Pendekatan Inkuiri Terbimbing. Jurnal Penelitian dan Pembelajaran IPA Vol. 2 (1): 60-67.

[17] Riyadi I.P, Prayitno B.A \& Marjono. 2015. Penerapan Model Pembelajaran Inkuiri Terbimbing (Guide Inquiry) pada Materi Sistem Koordinasi untuk Meningkatkan Keterampilan Proses Sains pada Siswa Kelas XI IPA 3 SMA Batik 2 Surakarta Tahun Ajaran 2013/2014. Jurnal Pendidikan Biologi Vol.2 (2): $81-86$

[18] Putra, R.S. 2013. Desain Belajar Mengajar Kreatif Berbasis Sains.Yogyakarta: Diva Press

[19] Brown, B.L. (2002). Improving Teaching Practices Action Research. Dissertation. Blacksburg Virginia.

[20] Nuayi, A.W., Supartin \& Buhungo, T.J. (2018). Stimulation Of Pressure On Liquid Concept In STAD Learning Model To Improve Rational Thinking Skills And Learning Outcomes Of 
Jurnal Luminous 1 (1) (2018) 1-9

Students. Jurnal Pendidikan Fisika Indonesia Vo. 14 (2): 83-91. 